\title{
Epidermal Renewal after Treatment of Primary Canine Hypothyroidism using Levothyroxine
}

\author{
Caroline Castagnara Alves', Stefanie Bressan Waller', Glícia Meneses Costa², Eduardo Gonçalves da Silva', \\ Matheus de Azevedo Soares' ${ }^{1}$, Thaíssa Gomes Pellegrin ${ }^{1}$, Amanda Leal de Vasconcellos ${ }^{3} \&$ Paula Priscila Correia Costa'
}

\begin{abstract}
Background: Primary canine hypothyroidism, an endocrine disorder that causes imbalances in the hypothalamus-pituitarythyroid axis, is a common cause of endocrine dermatoses, which frequently presents with opaque dry brittle hair. Tissue changes are also visible, such as myxedema, hyperkeratosis, epidermal atrophy, alopecia, and others. This paper describes the skin changes caused by primary hypothyroidism in a female dog before and after treatment with levothyroxine.

Case: This case study involved a 7-year-old Dalmatian bitch with a history of weight gain and changes such as rough dry brittle hair. For about a year, the dog also had also presented symmetrical erythematous and alopecia skin lesions in the regions of the hind limbs, lower back and tail, progressive lethargy and fatigue after exercise. A hemogram showed mild normocytic and normochromic regenerative anemia, as well as mild leukopenia and neutropenia. Biochemical tests revealed increased levels of creatinine, total cholesterol, and triglycerides. Skin biopsy revealed the presence of comedones in the epidermis and acanthosis and trichilemmal keratinization. Hormonal tests revealed high TSH and low free $\mathrm{T}_{4}$ and total $\mathrm{T}_{4}$ levels. A cervical ultrasound scan showed changes in the thyroid glands, with hypoechoic parenchyma, in addition to increased size of the right lobe, suggesting thyroiditis. Based on these exams, the patient was diagnosed with primary hypothyroidism, and treatment with levothyroxine was instituted.

Discussion: Around $90 \%$ of dogs with hypothyroidism show a decrease in total $\mathrm{T}_{4}$ and about $65-75 \%$ of them show an increase in TSH levels. In endocrinopathy, there is a decrease in the expression of $\mathrm{T}_{3}$ receptors in the keratinocytes and genes responsible for epidermal renewal. Also, molecules that affect epidermal differentiation bind to intracellular receptors belonging to the steroid/thyroid hormone superfamily. In this study, however, the application of the minimum levothyroxine dose restored the normal epidermal pattern for the species and the remaining parameters returned to normal. The hormone $\mathrm{T}_{3}$ acts in the differentiation of keratinocytes, a fact that, although not yet proven, is believed to be indirect and mediated by the epidermal growth factor or by the expression of the genes responsible for the renewal of the epidermis. Besides, some effects on the epidermis caused by deficiency of thyroid hormones may be due to secondary vitamin A deficiency, which is necessary for epithelial differentiation and binding epidermal growth factor (EGF) to the cell. Still, there is a theory that sex hormones also affect the differentiation of the epidermis, as studies show that deficiency causes effects similar to those caused by hypothyroidism. Some studies indicate the investigation of the relationship between secondary vitamin D deficiency and the increased cellularity of the epidermis of the spayed hypothyroid female rats. Additionally, the mechanism of the formation of hyperkeratosis in hypothyroidism is not yet elucidated. $\mathrm{T}_{3}$ is known to regulate keratin gene expression and perhaps also epidermal maturation, epithelial cycle, and normal keratin synthesis. The single treatment with levothyroxine in the female dog was effective in promoting the restoration of gene expression to $\mathrm{T}_{3}$ in keratinocytes.
\end{abstract}

Keywords: dermatopathies, endocrinopathies, hypothyroidism, levothyroxine, synthetic hormone. 


\section{INTRODUCTION}

Hypothyroidism, a common endocrine disorder in dogs, causes imbalances in the hypothalamic-pituitary-thyroid axis [3,12], affecting the synthesis of the hormones thyroxine $\left(\mathrm{T}_{4}\right)$ and triiodothyronine $\left(\mathrm{T}_{3}\right)$ [1]. This disease, which can be classified as primary, secondary, or tertiary $[3,12]$, can lead to irreversible pathological changes in the thyroid gland, and even to congenital anomalies in the thyroid and/or pituitary glands [5]. This reduces the gene expression of cell receptors for the hormone $\mathrm{T}_{3}$ in keratinocytes, as well as in the genes responsible for epidermal renewal [4]. Therefore, clinical signs such as a matte, brittle and dry coat are common [13], and this disease is the main cause of endocrine dermatoses in dogs [4].

Dermatological changes caused by hypothyroidism in animals must be taken into account by the veterinarian, since a decline in thyroid hormones keeps hair follicles in the telogen phase, that is, the resting phase [13]. Thus, tissue changes such as myxedema, hyperkeratosis, epidermal atrophy, alopecia, and changes in the composition of collagen and elastic fibers are characteristic of this endocrinopathy [4].

There are various treatments for hypothyroidism, one of the most common ones being the synthetic hormone levothyroxine $\left(\mathrm{LT}_{4}\right)$, which can be used in combination with triiodothyronine or alone [15]. This paper reports on the dermatological changes observed in a case of canine hypothyroidism before and after the use of levothyroxine, highlighting the effectiveness of using solely this synthetic hormone in low doses.

\section{CASE}

A 7-year-old spayed Dalmatian bitch weighing $36 \mathrm{~kg}$ was treated at the Bom Pra Cachorro Veterinary Clinic in Fortaleza, Ceará. The patient had a history of weight gain, skin changes, progressive lethargy, and exercise fatigue that had lasted for about 1 year. A physical examination revealed a rough brittle lackluster coat, in addition to symmetrical erythematous and alopecia skin lesions in the cervical region (Figure 1A), hind limbs, lower back and tail (Figure 1B). Her body temperature was within the physiological $\left(38.2^{\circ} \mathrm{C}\right)$, her mucous membranes were pink and moist, and her capillary filling time was normal for the species $(<2 \mathrm{~s})$.

Hematological exams revealed mild normocytic and normochromic regenerative anemia, as well as mild leukopenia and neutropenia. Biochemical tests indicated increased creatinine $(2.1 \mathrm{mg} / \mathrm{dL})$, total cholesterol (528 $\mathrm{mg} / \mathrm{dL}$ ), and triglycerides (202 mg/dL) levels, while the other analytes (alkaline phosphatase, ALT, and urea) were considered normal. Upon suspicion of hypothyroidism, a cervical ultrasound scan was performed, which revealed changes in the right (Figure 1C) and left (Figure 1D) thyroid glands. These glands presented hypoechoic parenchyma, the right lobe being enlarged, suggesting thyroiditis, in addition to the presence of 2 oval hypoechoic structures with irregular contours. A biopsy of skin lesions revealed trichilemmal keratinization (Figure 2A) and the presence of comedones and acanthosis in the epidermis (Figure 2B). Hormonal tests indicated an increase in TSH $(0.65 \mathrm{ng} / \mathrm{mL})$ and a decrease in free $\mathrm{T}_{4}$ $(0.11 \mathrm{ng} / \mathrm{mL})$ and total $\mathrm{T}_{4}(0.44 \mathrm{ng} / \mathrm{mL})$. These findings confirmed the clinical suspicion of primary hypothyroidism, and treatment was started with a minimal dose of levothyroxine (Puran $\left.\mathrm{T} 4^{\circledR}\right)^{1}[0.913 \mathrm{mg}$, every $12 \mathrm{~h}]$.

\section{DISCUSSION}

Given that hypothyroidism is confirmed by hormonal tests [10], the endocrine disorder in the canine patient was confirmed based on high TSH levels and low free $\mathrm{T}_{4}$ and total $\mathrm{T}_{4}$ levels. Approximately $90 \%$ of dogs with hypothyroidism show a decrease in total $\mathrm{T}_{4}$, while $65-75 \%$ of them show an increase in $\mathrm{TSH}$ concentration, serving as important hormonal markers for the identification of primary hypothyroidism [10].

In hypothyroidism, there is a decrease in the expression of $\mathrm{T}_{3}$ cell receptors in keratinocytes and of genes responsible for the renewal of the epidermis. This condition drastically affects the differentiation of the individual' s keratinocytes, since the molecules essential for epidermal differentiation, such as retinoids, vitamin $\mathrm{D}$, and $\mathrm{T}_{3}$ hormone, bind to such intracellular receptors, which belong to the steroid-thyroid hormone superfamily [4]. Due to the reduction of gene expression for the formation of receptors, fewer connections are formed between these molecules and the receptors, impairing the differentiation of keratinocytes. After hormonal treatment with a minimal dose of levothyroxine (Puran $\mathrm{T} 4{ }^{\circledR}$ ), the epidermal pattern was restored, revealing normalization of the cutaneous structures, as indicated by the histopathological findings.

This effect is explained by the fact the hormone $\mathrm{T}_{3}$ acts in the differentiation of keratinocytes, and that this action is believed to be indirect and mediated by the epidermal growth factor (EGF) or by the expression 
of genes responsible for epidermal renewal [6,7]. Both hyperthyroidism and hypothyroidism cause changes in the epidermis, and the signs they cause are more evident in the concentration of thyroid hormones in hypothyroidism. Also, increased loss of skin elasticity and hair are observed in hypothyroidism [9], both of which were present in the patient in the reported case.

Another factor that could aggravate clinical signs would be vitamin A deficiency, since it seems to be related to the cutaneous effects caused by hypothyroidism. This vitamin is necessary for epithelial differentiation and binding of EGF to the cell [4]. It is known that the molecules that affect epidermal differentiation bind to intracellular receptors of the steroid- -thyroid hormone superfamily, regulating keratinocyte differentiation and gene transcription [14]. In the case in question, the correlation between dermatopathy and vitamin A deficiency could not be determined because it was not measured in biochemical tests. However, the possibility of such a correlation is described in the literature. In view of the interrelation between hormones and other molecules in the skin, possible causes of secondary vitamin A deficiency should be considered, since they may lead to changes in the conversion of the corneal layer [2,11].

It is believed that sex hormones also affect epidermal differentiation, since their deficiency has caused effects similar to those of hypothyroidism in

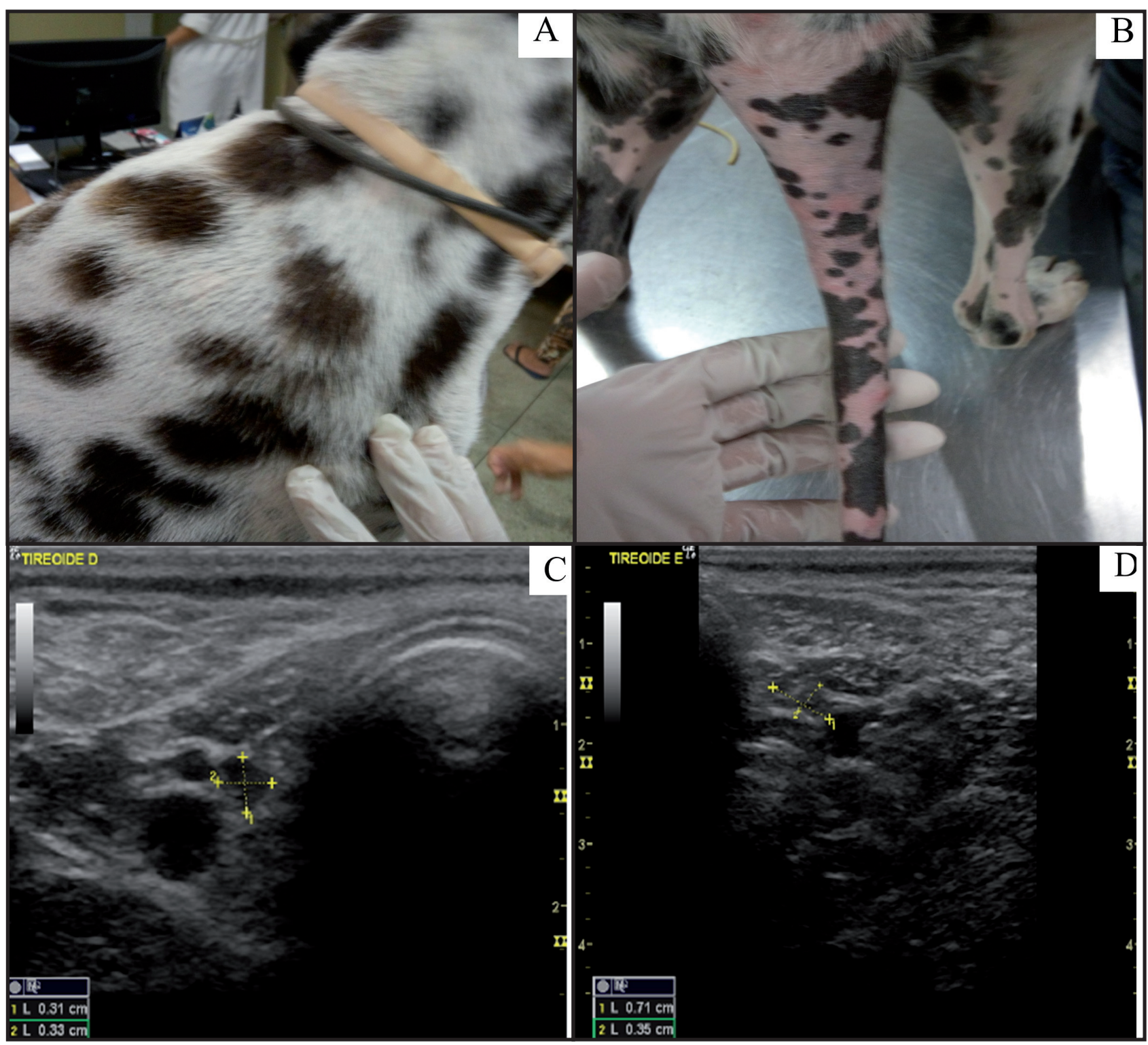

Figure 1. A 7-year-old spayed Dalmatian bitch with primary hypothyroidism. Erythematous and alopecic skin lesions in the scapular (A) and low back, tail and hindlimb regions (B). Cervical ultrasound scans showed hypoechoic content in the right (C) and left (D) thyroid glands, with an increase in size and the presence of irregular shaped oval structures in the right thyroid. 


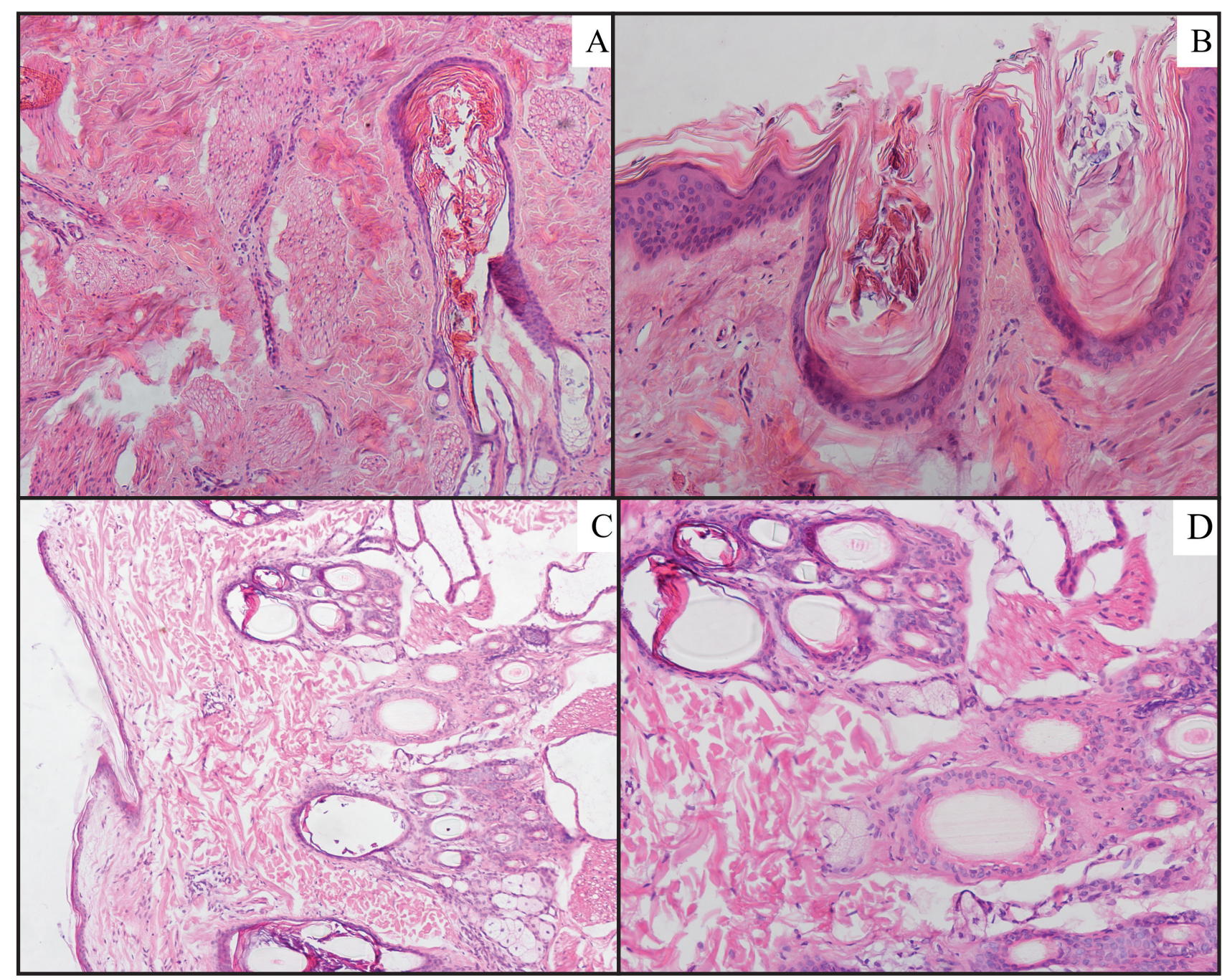

Figure 2. Histopathology of skin biopsy of a 7-year-old spayed Dalmatian bitch with primary hypothyroidism before treatment, revealing: A- Trichilemmal keratinization and vacuolization of the piloerector muscle [HE; 10x], and B- Comedones and acanthosis in the epidermis [HE; 20x]. After 5 months of treatment with a minimal dose of levothyroxine, a new biopsy revealed normalization of the epidermal structures C- [HE; 10x] \& D- [HE; 20x].

other studies [4]. Thus, we can understand that the performance of ovarian salpingohysterectomy in females can cause dermatological changes, since spayed and neutered animals will undergo a sudden decrease in the concentration of sex hormones due to the removal of their gonads.

The association of hypothyroidism with neutering was evaluated experimentally in a murine model, in which changes in the epidermis of spayed female rats with hypothyroidism were compared with healthy spayed female rats [4]. The study concluded that neutering associated with hypothyroidism reduces the synthesis of vitamin D3 (1,25-dihydroxyvitamin D3), which is necessary to inhibit proliferation and stimulate differentiation of keratinocytes [4], thus controlling epithelial function. We therefore assumed that the dermatological signs exhibited by the patient were caused by an endocrinopathy, and that the patient's previous spaying acted as an agonist. For a better understanding of the case, a dosage of vitamin D3 would be necessary, which was not applied in this study.

It is known that the hormone $\mathrm{T}_{3}$ directly regulates the expression of keratin genes [8], and probably also epidermal maturation, the epithelial cycle, and the normal synthesis of keratins. However, the mechanism of the pathogenesis of hyperkeratosis in hypothyroidism has yet to be elucidated.

This paper reported skin changes caused by canine primary hypothyroidism, in which the female dog showed clinical improvement after treatment with levothyroxine. The normalization of epidermal structures after hormonal therapy implies the restitution of gene expression of the hormone $\mathrm{T}_{3}$ at the level of keratinocytes. The histopathological evaluation of skin lesions via biopsy, the hormonal dosage, and ultrasound scanning of the thyroid glands are auxiliary 
methods for the diagnosis of primary hypothyroidism and should be considered in clinical cases with cutaneous signs of endocrinopathies.

MANUFACTURER

${ }^{1}$ Sanofi-Aventis Farmacêutica Ltda. São Paulo, SP, Brazil.

Acknowledgements. The authors gratefully acknowledge the
Brazilian research funding agencies CAPES (Federal Agency for the Support and Improvement of Higher Education) and CNPq (National Council for Scientific and Technological Development) for the fellowships awarded to them.

Declaration of interest. The authors report no conflicts of interest. The authors alone are responsible for the content and writing of the paper.

\section{REFERENCES}

1 Bilhalva M.A., Evaristo T.A., Isnardi C.P., Rocha M.M., Alves C.C., Soares M.A., Waller S.B., Borba A., Santos T.C. \& Costa P.P.C. 2020. O hipotireoidismo canino e seus efeitos sobre o sistema cardiovascular. PUBVET. 14(4): 1-6. DOI: 10.31533/pubvet.v14n4a542.1-6.

2 Feingold K.R. \& Elias P.M. 1987. Endocrine-skin interactions: Cutaneous manifestations of pituitary disease, thyroid disease, calcium disorders, and diabetes. Journal of the American Academy of Dermatology. 17: 921-940. DOI: $10.1016 / \mathrm{S} 0190-9622(87) 70282-5$

3 Ferguson D.C. 2007. Testing for Hypothyroidism in Dogs. Veterinary Clinics of North America: Small Animal Practice. 37(4): 647-669. DOI: 10.1016/j.cvsm.2007.05.015.

4 Ferreira E., Serakides R., Nunes V.A., Gomes M.G., Silva C.M., Ocarino N.M. \& Ribeiro A.F.C. 2003. Morfologia e histoquímica da pele de ratas hipotireóideas castradas e não castradas. Arquivo Brasileiro de Medicina Veterinária e Zootecnia. 55(1): 51-60. DOI: 10.1590/S0102-09352003000100008.

5 Graham P.A., Refsal K.R. \& Nachreiner R.F. 2007. Etiopathologic findings of canine hypothyroidism. Veterinary Clinics of North America: Small Animal Practice. 37(4): 617-631. DOI: 10.1016/j.cvsm.2007.05.002.

6 Grando S.A. 1993. Physiology of endocrine skin interrelations. Journal of the American Academy of Dermatology. 28: 281-292. DOI: 10.1016/0190-9622(93)70141-F.

7 Hoath S.B., Lakshmanan J., Scott S.M. \& Fisher D.A. 1983. Effect of thyroid hormones on epidermal growth factor concentration in neonatal mouse skin. Endocrinology. 112: 308-314. DOI: 10.1210/endo-112-1-308.

8 Ohtsuki M., Tomic-Canic M., Freedberg I.M. \& Blumenberg M. 1992. Regulation of epidermal keratin expression by retinoic acid and thyroid hormone. The Journal of Dermatology. 19: 774-780. DOI: 10.1111/j.1346-8138.1992. tb03779.x.

9 Ozmen O.\& Topsakal S.2020. Examination of skin lesions in rats with induced hyperthyroidism and hypothyroidism. Biotechnic \& Histochemistry. 95(6): 438-444. DOI:10.1080/10520295.2020.1714731

10 Panciera D.L. \& Carr A.P. 2007. Hipotiroidismo. In: Endocrinologia para o Clínico de Pequenos Animais. São Paulo: Editora Roca, pp.26-36.

11 Prasad R., Kumar V., Kumar R. \& Singh K.P. 1999. Thyroid hormones modulate zinc transport activity of rat intestinal and renal brush border membrane. American Journal of Physiology. 276: 774-778. DOI: 10.1152/ ajpendo.1999.276.4.E774.

12 Scott-Moncrieff J.C. 2007. Clinical Signs and Concurrent Diseases of Hypothyroidism in Dogs and Cats. Veterinary Clinics of North America: Small Animal Practice. 37(4): 709-722. DOI: 10.1016/j.cvsm.2007.03.003.

13 Teixeira R.S. 2008. Hipotireoidismo em cães dermatopatas: aspectos clínico laboratoriais comparados ao exame histopatológico da pele. 99f. Seropédica, RJ. Dissertação (Mestre em Ciências) - Curso de Pós-Graduação em Medicina Veterinária, Universidade Federal Rural do Rio de Janeiro.

14 Törmä H., Rollman O. \& Vahlquist A. 1993. Detection of mRNA transcripts for retinoic acid, vitamin D3, and thyroid hormone (c-erb-A) nuclear receptors in human skin using reverse trancription and polymerase chain reaction. Acta Dermato-Venereologica. 73(2): 102-107. DOI: 10.2340/0001555573102107.

15 Vinagre A.L.M. \& Souza M.V.L. 2011. Interferências na absorção de levotiroxina e dificuldades no manuseio de pacientes com hipotireoidismo na unidade de terapia intensiva: relato de dois casos e revisão de literatura. Revista Brasileira de Terapia Intensiva. 23(2): 242-248.

http://seer.ufrgs.br/ActaScientiaeVeterinariae

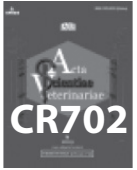

